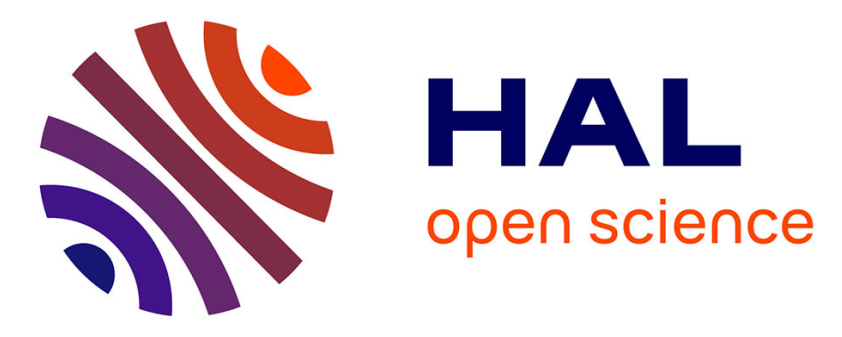

\title{
DRY biorefineries: Multiscale modeling studies and innovative processing
}

Claire Mayer, Abdellatif Barakat, Cecile Barron, Jean-Yves Delenne, Xavier

Frank, Frédéric Mabille, Xavier Rouau, Abdelkrim Sadoudi, Marie-Francoise Samson, Valerie Lullien-Pellerin

\section{To cite this version:}

Claire Mayer, Abdellatif Barakat, Cecile Barron, Jean-Yves Delenne, Xavier Frank, et al.. DRY biorefineries: Multiscale modeling studies and innovative processing. Innovative Food Science \& Emerging Technologies / Innovative Food Science and Emerging Technologies , 2018, 46, pp.131-139. 10.1016/j.ifset.2017.08.006 . hal-01606747

\section{HAL Id: hal-01606747 https://hal.science/hal-01606747}

Submitted on 26 May 2020

HAL is a multi-disciplinary open access archive for the deposit and dissemination of scientific research documents, whether they are published or not. The documents may come from teaching and research institutions in France or abroad, or from public or private research centers.
L'archive ouverte pluridisciplinaire HAL, est destinée au dépôt et à la diffusion de documents scientifiques de niveau recherche, publiés ou non, émanant des établissements d'enseignement et de recherche français ou étrangers, des laboratoires publics ou privés.

\section{다(1)(2)}

Distributed under a Creative Commons Attribution - ShareAlikel 4.0 International 


\section{Accepted Manuscript}

DRY biorefineries: Multiscale modeling studies and innovative processing

C. Mayer-Laigle, A. Barakat, C. Barron, J.Y. Delenne, X. Frank, F. Mabille, X. Rouau, A. Sadoudi, M.-F. Samson, V. LullienPellerin

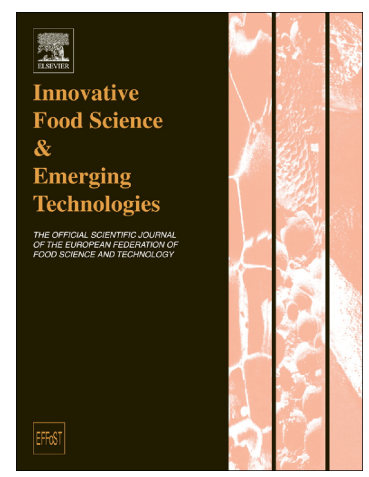

PII:

S1466-8564(17)30232-1

DOI: doi: 10.1016/j.ifset.2017.08.006

Reference: INNFOO 1825

To appear in: Innovative Food Science and Emerging Technologies

Received date: 23 February 2017

Revised date: 5 July 2017

Accepted date: 10 August 2017

Please cite this article as: C. Mayer-Laigle, A. Barakat, C. Barron, J.Y. Delenne, X. Frank, F. Mabille, X. Rouau, A. Sadoudi, M.-F. Samson, V. Lullien-Pellerin , DRY biorefineries: Multiscale modeling studies and innovative processing, Innovative Food Science and Emerging Technologies (2017), doi: 10.1016/j.ifset.2017.08.006

This is a PDF file of an unedited manuscript that has been accepted for publication. As a service to our customers we are providing this early version of the manuscript. The manuscript will undergo copyediting, typesetting, and review of the resulting proof before it is published in its final form. Please note that during the production process errors may be discovered which could affect the content, and all legal disclaimers that apply to the journal pertain. 


\title{
DRY biorefineries: multiscale modelling studies and innovative processing
}

C. Mayer-Laigle, A. Barakat, C. Barron, J.Y. Delenne, X. Frank, F. Mabille, X. Rouau, A. Sadoudi, M.-F. Samson, V. Lullien-Pellerin

UMR IATE, CIRAD, INRA, Montpellier SupAgro, U. Montpellier, 2 Place Viala, 34060 Montpellier, France

Corresponding author: $V$. Lullien-Pellerin, tel: +33 (4) 99613105 - fax: +33 (4) 99613076 - e-mail: valerie.lullien-pellerin@inra.fr

Keywords: agro-resources, energy, grinding, mechanics, pre-treatment, separation

\begin{abstract}
This paper reviews studies on green resource fractionation for two different types of material displaying a lignocellulosic or granular-type structure or a composite of the two. It explains how the identification of specific biochemical or spectral markers helps monitor tissue fate along processing and thus increase our knowledge on material fractionation. The key role of tissue mechanical properties in fracture behavior and the value of characterizing them were highlighted to better understand particle composition and properties. The effect of different modes of mechanical stress and strain during grinding as the main step of fractionation was illustrated. The value of different types of pre-treatment before or at grinding to reduce energy required to fracture and enhance dissociation or compound accessibility was presented. Separation methods based on differences in properties of the generated particles, and particularly innovative developments based on electrostatic sorting, were reviewed.
\end{abstract}

\section{Introduction}

Dry biorefining emerges as the most appropriate processing technology to help develop products (food, packaging, bio-chemicals, energy, etc.) made with renewable resources in a sustainable chain. Dry biorefining helps economize water and avoids energy consumption in drying operations. It is traditionally undertaken to convert cereal grains by grinding them into particles (between 30 and $1500 \mu \mathrm{m}$ ) ready to be further classified by sieving. Depending on their biochemical composition and specific properties, these particles are used to make cereal products like bread, pasta, semolina or biscuits or to serve for feeds or production of energy. Plants material is a heterogeneous structure made of distinct organs (stem, grains, leaves, etc.), each composed of different tissues with specific composition and structure. The way they break under process stress will thus determine the composition of the particles produced. Moreover, a heterogeneous particle can be transformed into a homogeneous one if its size is sufficiently reduced by grinding. This will open the way to tissue or even molecular isolation. The fracture behavior of the raw material or its component tissues depends on its mechanical properties, which can be characterized and are related to the material's structure and biochemical composition. This makes it important to gain better knowledge of the raw material fracture behavior in order to better understand and further control the biochemical composition and 
properties of the particles produced. A multidisciplinary approach is needed to characterize the structure, biochemical composition and mechanical properties of the raw material and establish their relationships with fracture behavior. This same approach will also help develop simulation models that predict grinding process behavior-models that will also usefully expand the natural variability raw matter and help define the "ideal" or most appropriate material to optimize end-to-end process energy expenditures.

Two objects of study appear particularly suitable for dry biorefinery behavior analysis:

- the lignocellulosic material making up the cell walls of wood tissues, stems, straw, and the outer grain tissue. Lignocellulosic material presents interesting properties in itself and is a source of potential molecules of interest for producing renewable energy (cellulose) or green molecules for packaging or chemistry applications (lignin);

- a granular-type material found in the inner grain tissue (i.e. cereal endosperm or leguminous cotyledons). It is mainly composed of starch granules surrounded by a protein matrix with a distinct level of adhesion between the two polymers.

Depending on the scale of the analysis-subcellular, tissue or plant organ - the green resources correspond to either one of these two objects of study or a composite of both. Monitoring the through-processing fate of each tissue or subcellular part starts with first defining specific markers. The first part of this review mainly describes how characterizing the biochemical composition of the different tissues helps reveal their fracture behavior and how knowledge of their physical properties helps understand or even modulate their fate through processing. We also explain how determining the biochemical composition and structure of the studied objects helps develop models for predicting breaking behavior. The second part of this review analyzes each processing step and illustrates how it can be modulated or re-engineered to better control the particle properties or develop molecular separation.

\section{Tissue-scale characterization}

The example of cereal grain offers a good illustration (Fig. 1.) of how the agro-resources displays a complex structure made of different tissues with distinct biochemical composition and structure and, therefore, distinct physical properties. Cereal grain is usually transformed by milling processes which couple successive steps of grinding and then sieving the particles produced to recover the grain's inner part, found in the finest particles which are used to make cereal food products for human consumption, from the other parts found in the largest particles. These processes roughly separate the endosperm tissue made of starch particles in a protein matrix from the other tissues, and the efficiency of this separation is classically monitored by ash measurement, as ash concentration increases from the grain heart to the periphery. These recent years pressure has been growing to improve the quality of the cereal products by increasing their micronutrient and fiber content (mainly found in the aleurone layer; Antoine et al. 2002) without increasing the levels of contaminants (mycotoxins produced by grain-infesting fungi, grain storage pesticides or heavy metals) that can find their way into the most peripheral tissues (outer pericarp and the other outer layers). The classical ash marker was clearly insufficient to achieve this goal. Furthermore, there has been renewed investigation into the potential for better value-streaming of the grain milling fractions not used for human consumption. Indeed, if not used to make food products, green 
materials constitute a source of potentially valuable polymers for food ingredients or non-food uses, like gluten, starch, $\beta$-glucans, cellulose, lignins, phenolic compounds, among others.

\subsection{Simple tissues (microscale)}

2.1.1 Biochemical composition of tissues and identification of specific markers to monitor processing

It was important to accurately identify the biochemical composition of each tissue in order to determine the location of potential molecules of interest (as done for taxifolin in Douglas fir bark; Trivaleto et al., 2016). It was also useful to identify any molecules only or mainly located in one tissue, which could therefore be used as markers to monitor the corresponding tissue in the different fractions obtained depending on the process employed. Getting such markers requires the isolation of pure tissues and the quantification of specific molecules. Tissue proportion can then be deduced from the concentrations of biochemical markers in the fractions compared to those in pure tissues. As an example, for common wheat grains, it is possible to isolate some of the main tissues by handdissection (Surget \& Barron, 2005). Using this approach, it was found that starch quantification could serve as a marker of the starchy endosperm, whereas aleurone layer, testa, outer pericarp and embryo were found to be efficiently monitored by measuring phytic acid, alkylresorcinols, trimeric form of ferulic acid and wheat germ agglutinin, respectively (Hemery et al., 2009a). It was also found possible to distinguish markers for monitoring subcellular structures: $p$-coumaric acid was used to quantify aleurone cell walls, whereas phytic acid was found to mark aleurone intracellular globoids.

\section{Fig. 1}

This methodology appeared useful to finely characterize the distribution of the main grain tissues in common wheat grain milling fractions, such as coarse bran, and to further monitor their fractionation according to particle size (Antoine et al., 2004a, 2004b) or according to different grinding or particle separation conditions (Hemery et al. 2011a, 2011b). This procedure was also found to efficiently demonstrate differences in aleurone layer fractionation between wheat grains differing by hardness (Greffeuille et al., 2005). Furthermore, it proved easily transposable to durum wheat studies (Barron et al., 2011a) and was used to monitor tissue distribution over the course of debranning or after milling (Raggiri et al., 2016; Rios et al., 2009). Some of these biochemical markers could also be used to monitor tissues from other small cereal grains, as shown for barley (Mayolle et al., 2012).

Due to their specific biochemical composition, wheat grain tissues were shown to display different spectroscopic responses in the mid-infrared range or in Raman and autofluorescence spectroscopies (Barron \& Rouau, 2008; Jensen et al., 1982). These properties were used to identify and even quantify some of the grain tissues after their size reduction into powder (Barron, 2011b; GalindezNajera et al., 2016; Jensen et al., 1982; Symons \& Dexter, 1996). Compared to biochemical marker quantification, spectroscopic tissue fingerprinting is a simpler and quicker method, but it does not offer the same accuracy for all of the tissues and cannot separately distinguish the aleurone cell walls from the intracellular medium. However, spectral identification coupled with imaging paves the way to obtaining tissue distribution within particles and then to evaluating the dissociation of biological tissues directly after grinding (Corcel et al., 2016). 


\subsubsection{Characterization of tissues and their constitutive polymer physical properties}

Hand-dissection of wheat grain tissues has also enabled further characterization of their physical properties. Antoine et al. (2004c) demonstrated distinct resistivity and capacity of the most peripheral grain tissues from the outer pericarp to the aleurone layer. However, relative values of these dielectric properties also depend on tissue water content. These differences in tribo-charging potential were found useful to develop other separation methods than sieving ground tissues, especially when ultrafine particles were obtained (Hemery et al., 2009b, 2011b).

As grinding is the first step in material fractionation, it was important to determine the mechanical properties of wheat grain tissues in order to better control the energy required to grind and optimize the later sieving separation conditions, i.e. to amplify size differences in particles of the tissues to be separated. Indeed, tension tests until rupture on hand-isolated tissues showed differences in the mechanical properties of the tissues making up the wheat grain outer layers (Antoine et al., 2003). These properties were found to depend on tissue water content, as expected, but also on temperature (Hemery et al., 2010a). The pericarp layer was found to break differently to the other outer-layer grain tissues at moisture contents below $16 \%$. This means that the tissues were possible to separate under these conditions, whereas at higher moisture content, all of the outer layers increased their extensibility and broke similarly, thus making them impossible to separate. Tissue extensibility and mechanical energy to fracture was found to positively correlate with temperature. Under $-50^{\circ} \mathrm{C}$, the outer pericarp was found to display almost no resistance to fracture whereas the aleurone layer was still elastoplastic and the tissues between the two were brittle, making it easier to reduce the size of the overall outer-layer grain tissues. These relationships between mechanical properties and temperature or wetness conditions could thus be useful to optimize processing. Moreover, the extensibility of grain peripheral tissues was also shown to differ depending on common wheat hardness (Greffeuille et al., 2007), with tissues from soft grains being more extensible. These contrasting mechanical properties could be related to the differences in size distribution of the bran particles obtained from milling, which mostly come from these outer-layer grain tissues (Greffeuille et al., 2006a).

The mechanical resistance of the grain's inner part, i.e. the starchy endosperm which makes up the majority of the grain (80-85\%), was also explored. As the endosperm is made of starch granules measuring between 5 and $30 \mu \mathrm{m}$ embedded in a protein matrix (gluten), an original scratching AFM method was developed. This method was used to probe the starch surface $\left(1 \mu \mathrm{m}^{2}\right)$ and to explore in depth the mechanical properties of the surrounding protein network and its potential interfaces (Chichti et al., 2013). The method showed that protein had lower mechanical properties (close to talc, around $0.6 \mathrm{GPa}$ ) than starch (close to calcite, around 2.4 GPa), and also identified differences in mechanical behavior at the protein-starch interface depending on wheat grain hardness. These differences appeared to correlate well with the presence of specific proteins called puroindolines, which were hypothesized to play a lubricant role at this interface, in soft grains where they are present in the wild-type forms (Chichti et al., 2015). Absence of adhesion between constitutive polymers in the soft starchy endosperm could explain why flours obtained from grain grinding displayed distinct particle size profile distributions. Soft common wheat grains showed a bimodal particle size distribution with one peak around the size of starch granules, whereas flours from hard common wheat grains, carrying mutated puroindolines or lacking one of them, showed a monomodal distribution (Greffeuille et al., 2006b). 
At tissue scale, parallelepiped-shaped samples made in the grain starchy endosperm were submitted to compression tests in order to characterize their mechanical properties. Mechanical properties were found to depend mainly on grain hardness (Greffeuille et al., 2006b; Haddad et al., 2001), which can be controlled by selecting the appropriate wheat cultivar (soft versus hard common wheat) or species (common wheat versus durum wheat) as it is linked to a specific genetic locus on chromosome 5 of the D-genome. Mechanical properties were also found to depend on endosperm water content and on endosperm vitreousness, a characteristic related to the porosity of the structure and generally assessed by visual evaluation on cut grains. Table 1 summarizes the data measured in compression tests on samples made in the starchy endosperm from two near-isogenic wheat lines differing only by hardness and grown in contrasted environments to obtain mealy or vitreous grains differing only by porosity level. The data clearly shows the impact of hardness and vitreousness on endosperm mechanical properties. Grains from the hard-isogenic line were found to display higher maximum stress ( $\sigma \max$ ) and strain $(\varepsilon \max )$ values and total energy to rupture (W) than grains from the soft line. Stiffness (E) was found to increase sharply with vitreousness for both lines. The vitreousness effect on mechanical properties was more pronounced with the hard wheat line, as stress and energy to rupture was multiplied two-fold.

\section{Table 1}

\subsection{Associated tissues/organs (mesoscale)}

\subsubsection{Grinding energy measurements and cohesive and adhesive properties}

An instrumented micromill equipped with on-line torque transducers was developed (Pujol et al., 2000 ) to record energy consumption during milling on small quantities of grains ( $\geq 100 \mathrm{~g}$ ). The micromill also affords the correspondingly reduced particles, as flours, which can be quantified and characterized. Table 1 summarizes the data obtained at first break from the same wheat samples used for the characterization endosperm mechanical properties. The data reveals significant differences between energy required to break hard grains compared to soft grains, whatever the wheat growing conditions. Vitreous kernels were found to produce less flour than mealy ones, and therefore required more energy to produce a similar flour yield in comparison with mealy samples as measured by $\mathrm{K}^{\prime}$. As already observed when studying endosperm mechanical properties, the vitreousness effect on mechanical resistance was more pronounced with the hard wheat line, and total energy to rupture the endosperm samples was well correlated with energy required to break the grains. Moreover, this energy required, which depends on both hardness and vitreousness, was found to directly impact the starch damage level in the flour, which is a key characteristic as it leads to differences in water absorption when the flour is later used to make food products (Morrison \& Tester, 1994). Therefore, both the adhesion between constitutive polymers (depending on hardness and controlled by genetic factors) and the porosity of the starchy endosperm (depending on growth conditions) affect the required grinding energy and end-properties of the flour.

New methodologies were developed to estimate either the cohesion of each biological tissue or their adherence within a multilayered system. Specific attention was paid to evaluate tissue cohesion directly in structured organs, thus avoiding dissection steps and potential associated artifacts. Cohesion of tissues was related to ablation thresholds using pulsed laser (Martelli et al., 2009, 2010a) or their ionization effectiveness using laser-induced breakdown spectroscopy (LIBS) (Martelli et al, 2011). In wheat grains, cohesion of the overall constitutive tissues-even those not possible to isolate by hand-dissection - was studied in their native state. Testa was then singled out, for the first 
time, as the most cohesive tissue within the outer layers. These methodologies have paved the way to screening for differences between cultivars, and a dedicated micromechanical device has been developed to probe biological tissue adherence. In wheat grains, adherence at the interface between the nucellus and the aleurone layer was studied through peel tests (Martelli et al., 2010b), and adherence distribution around the wheat grain was investigated, and it was found that adherence was lower around the germ at the grain basal part. Even though interpreting peel forces is complex task, this methodology could be appropriate to evaluate differences among cultivars or to test the effects of pre-treatment in wheat processing.

The mechanical properties of the wheat grain outer layers were found to change following enzymatic oxidative pre-treatments with exogenous peroxidases in order to modify the cell-wall polymer interactions (Peyron et al., 2001). The change was found to occur at the interface between tissues. Similarly, Desvignes et al. (2006) showed that activating the potential of endogenous peroxidases also leads to changes in the mechanical properties of the wheat grain outer layers.

\subsubsection{Numerical modeling of plant fragmentation}

Cracking and fractionation issues can be tackled using numerous theoretical approaches, among which lattice-based methods are particularly well suited to heterogeneous materials like green resources marked by a complex histology (Topin et al., 2007). These approaches have been successfully employed with image analysis to help describe wood mechanical properties at subcellular scale (Perre et al., 2016) or phase distribution models for wheat endosperm modeling (Topin et al., 2008). The different phases and interfaces are discretized using one-dimensional elements, such as breakable linear springs (Fig. 2a). Their location in starch or protein network or void helped derive the stiffness and failure stress of the springs thanks to the mechanical measurements made on wheat endosperm by AFM (Chichti et al., 2013). In the elastic regime, there was very good agreement with experimental tests (Chichti et al., 2016). The numerical stress-strain curves, failure properties, and evolution of starch damage (Fig. 2b) were studied in detail (Topin et al., 2009) for distinct 2-D microstructures differing in porosity-a parameter linked to vitreousnessand level of adhesion between polymers - a parameter linked to hardness. One important outcome was a map of starch damage levels as a function of starch-protein interfacial adhesion and protein volume fraction in the pore space (Topin et al., 2008). The results highlighted three clearly different starch granule failure regimes (Fig. 2c) and helped to better understand the role of both microstructure and starch-protein surface adhesion, which is related to genetic background through the lubricating action of puroindolines. Note that the simulations are not limited to the parameter range of available wheat varieties, and that the numerical procedure can help extrapolate features for the selection of future plant material. Finally, when dealing specifically with milling, it is important to account for dynamic effects caused by shockwave propagation. A promising approach was recently developed to focus on these effects, which lead to fracture branching and complex crack patterns.

Fig. 2

\section{Processing step studies and development}


The bio-refinery concept consists in fully exploiting the potential functionalities offered by green resources. It combines several unit operations to obtain different products with complementary uses, from foods and feeds to building-block molecules, agro-materials (fibers), biofuels or energy, with the ideal aim of squeezing value from the whole plant material. Grinding steps are the main operation for dry fractionation of these green resources, which fragments the raw materials. Intensive dry grinding enhances the reactivity of powdered products, and can be considered in itself as an efficient pretreatment of bulk biomass prior to further biotechnological processing, providing a sufficient reduction in particle size (Silva et al., 2011, Silva et al., 2012, Barakat et al., 2013).

Furthermore, the heterogeneity of the raw matter, for example the presence of a mix between granular and lignocellulosic materials in grains, generally makes it necessary to separate the obtained powders, which exhibit different compositions and properties, ready for further distinct value streams. This can be achieved by adding separation or classification unit operations to the fragmentation and dissociation steps. Keeping separation operations as dry processes is a particularly attractive avenue for sustainable development as dry processes have lower environmental impact. The techniques employed are based on physical and/or chemical differences between particles, typically differences in size, shape, density, or composition.

Physical, chemical or biochemical conditioning of the raw materials prior to grinding and separation could also improve the dissociation and recovery of specific fractions.

\subsection{Comminution and dissociation of plant materials}

In the field of biomass valorization, grinding generally consists of reducing the raw material into a target particle-size distribution, ideally using a little energy as possible. It also increases the accessibility of components for further chemical or enzymatic extraction (Barakat et al., 2014).

Biomass can be comminuted by a combination of chipping and grinding. Several types of size reduction are generally distinguished to dissociate plant material at different scales: cutting, crushing or coarse grinding ( $\mathrm{cm}$ to $\mathrm{mm}$ ) at plant-organ scale, intermediate comminution ( $\mathrm{cm}$ to $100 \mu \mathrm{m}$ ) at tissue scale, fine grinding $(<100 \mu \mathrm{m})$ at cell scale, and ultra-fine grinding $(<20 \mu \mathrm{m})$ as sub-cell scale.

At particle scale, the mechanical loading involved can be very complex to resolve. Particle size reduction is achieved by a combination of different mechanical forces resulting from impacts, compression, abrasion and shearing, all of which may coexist in the same equipment (Motte et al, 2015a). Fig. 3-a illustrates these main mechanical stresses and gives examples of equipment available that can dissociate material at tissue and/or cellular scale.

\section{Fig. 3}

Inside a mill, fracture paths propagate in preferential ways between or through the tissue/cells. The fracture depends on various parameters such as milling energy, mechanical loading at particle scale, mechanical properties of the plant materials and the defects in their microstructure, environmental conditions, and more. Milling thus produces a wide range of particles that differ in size, density, color, biochemical composition, and so on. For example, fracture propagation was shown to differ depending on wheat grain hardness, which generates distinct particle properties (Greffeuille et al., 2006b; Heinze et al., 2016). Recent studies on cork cells also showed that depending on the 
mechanical stresses generated by the equipment-either shear and compression or impact-fracture path either propagates through the cells or tends to bypass them (Motte et al., 2017).

Fig. 3-b illustrates the particle size distribution obtained after grinding oat bran starting material with different devices. Four peaks are distinguishable in the curves $(\leq 1 \mu \mathrm{m}, \approx 20 \mu \mathrm{m}, \approx 100 \mu \mathrm{m}, \approx 500 \mu \mathrm{m})$ but their relative importance varies according to equipment used. In this example, the impact generated using a jet mill appeared in efficient for oat bran grinding at cellular scale, as the grading curve counts just one major peak at $500 \mu \mathrm{m}$ (Fig. 3-b), whereas shearing generated by the high-shear mill led to two populations of particles that could be further separated, e.g. by air classification.

However, dissociation, which appears an essential pre-separation step, is not related solely to particle size reduction. Indeed, if the fracture path propagates in the same way through all of the tissues, the resulting particles will be "composite" and constituted of different tissues even if fine grinding is applied. In this case, there will be very few differences between particles, and the separation step will be less efficient. In contrast, if fracture path propagates preferentially between the different tissues, then a better dissociation, creating differences in size, composition and/or mechanical properties of the particles, could be achieved even if the particles are still coarse. As an example, a coarse milling of Douglas fir bark with a knife mill followed by simple sieving was recently shown to allow good separation of the different tissues (Trivelato et al, 2016).

Energy consumptions increases significantly with decreasing particle size (Barakat et al, 2013), and the separation processes are more difficult to undertake for the finest particles. In a sustainable processes perspective, it is important to adjust target particle size to expected level of dissociation. Thus, the choice of one milling technology over another must be adapted to the plant materials in order to accentuate the differences between particle properties and minimize the total energy consumption. To that end, a pretreatment step, either prior to or during the grinding step, can also be inserted in the processing chain.

\subsection{Pretreatment to decrease milling energy and enhance tissue dissociation or the biochemical compounds accessibility}

Changes in the green resources' mechanical properties can be obtained by pretreatments in order to potentially modulate their milling energy and their behavior during the grinding steps and/or enhance accessibility to compounds of interest. Pretreatments may be physical, chemical and/or biochemical. Drying and conditioning the raw materials is known to be the simplest. Indeed, moisture content and temperature were found to significantly influence the mechanical properties of isolated tissues (Hemery et al., 2010a) and thus potentially their grinding energy. However, to be efficient, the gain in grinding energy has to superior to drying energy. Due to the heterogeneity of the material, the water penetrates the different tissues in a different way, playing a plasticizing role and thus modifying their viscoelastic properties, which significantly influences their grinding behavior. This principle is particularly exploited in wheat grain processing during the conditioning step, where it allows better dissociation between the starchy endosperm and other tissues thanks to the greater differences in mechanical properties of the different tissues. Cryogenic grinding was also found to yield fine particles at less energy cost compared to room-temperature grinding (Hemery et al., 2011a) while also increasing phenolic acid bioaccessibility (Hemery et al., 2010b) and potentially preserving some heat-labile micronutrients. However, cryogrinding all of the bran-constitutive tissues frozen in the same way fails to exploit the differences in tissue mechanical properties and 
does not therefore enhance histological separation. Thus, ambient grinding has to be preferentially applied before cryogenic milling if tissue dissociation is required. Reduction of the mechanical resistance of wheat bran and grain was also observed after UV irradiation and was shown to be due not only to the hydrothermal history of the material but also to changes in the chemical interactions between the cell-wall polymers of outer-layer tissues (Peyron et al., 2002).

Based on knowledge of the effects of oxidative treatments on wheat-grain outer-layer mechanical properties, ozone was applied to wheat grains and shown to efficiently decrease grinding energy (Desvignes et al., 2008). However, even if ozone treatment also showed promise for decreasing potential grain contaminants, it comes with potential side effects that should be carefully analyzed to correctly evaluate the benefits of ozone treatment (Lullien-Pellerin, 2012). Lignocellulosic material fractionation using wet processing to obtain sugars for biofuel production often requires drastic conditions that use high amounts of solvent and energy, resulting in detrimental environmental impact. Recently, an innovative eco-friendly one-pot approach coupling chemical treatment under high solid-to-liquid-ratio conditions (5/1) and vibro-ball-milling was found to be the most efficient way to increase carbohydrate accessibility for enzymatic conversion at less solvent and energy cost. It was successfully applied to corn stover (Loustau-Cazalet et al., 2016) and sugarcane bagasse (Sambusiti et al., 2015).

Note too that anaerobic fermentation of wheat straw followed by grinding was shown to both reduce milling-specific energy consumption by up to $35 \%$ in comparison with untreated straw and to enhance bioethanol yields by up to $83 \%$ (Motte et al., $2015 \mathrm{~b}$ ).

\subsection{Separation processes}

Dry fractionation processes can integrate several separation techniques that exploit different properties of the particles: sieving based on particle sizes, aerodynamic sorting based on particle densities and shapes, and electrostatic sorting based on differences in particle composition. Electrostatic sorting is the most novel of the three for plant material dry refineries.

\subsubsection{Classical separation processes: sieving and aerodynamic sorting}

Sieves/screens are the oldest and most-widely used working elements for separating solid particles by size, and can effectively divide particles from a few centimeters down to a hundred microns in size. Air classification, which serves to classify particles both by size and aerodynamic sorting, was also found to successfully produce fractions with specific properties and even to obtain separation of the wheat flour components in protein- or starch-enriched fractions (Letang et al., 2002). More recently, finely-ground rice straw was also split by air classification into a lignin-rich fraction suitable for chemical valorization and a cellulose-rich fraction with improved performances in hydrolysis and fermentation yields (Chuetor et al., 2015). Another application of air classification involves selecting lignocellulosic particles as charges in bio-based composite materials. Indeed, the composite obtained showed distinct particle-size-dependent properties (Berthet et al., 2017).

\subsubsection{Innovative separation processes: electrostatic separation}

Electrostatic separation is quite recent in the field of plant product refining, and can integrate different techniques based on differences in particle charge acquisition and conductivity, mostly via two main types of devices using distinct principles: triboelectric separators and belt-type electrostatic separators. 


\subsubsection{Triboelectric separators (Fig. 4-a)}

These types of separators require that some of the particles present in the fraction for separation to be oppositely charged. Triboelectrification occurs when the particles are rubbed together and/or against an insulating material that induces electron and ions exchanges depending on the surface composition of the particles. Tribocharging is generally obtained in fluidized beds or pneumatic conveyor pipes. The mixture of charged particles is then separated in an electric field and collected as positive and negative fractions. Triboelectric separation was successfully used to classify particles of finely-ground wheat bran to yield powder fractions of different properties (Hemery et al., 2011b). Charge of the particles was related to their biochemical composition: particles from the pericarp layer, which is rich in highly-branched heteroxylans, were separated from particles from the aleurone cell-walls which contain $\beta$-glucans and more linear arabinoxylans. After recycling positive fractions on the separator, it was possible to obtain an aleurone-cell-wall-rich product with a yield of around onethird of the initial bran. Triboelectrostatic separation was used to obtain $\beta$-glucan-enriched fractions from oat bran preparations. Particles rich in $\beta$-glucans and starch were separated from particles containing arabinoxylans, enabling to obtain nearly $50 \%$-enrichment in $\beta$-glucans from defatted finely-ground oat-bran. Further jet-milling and air-classification was able to increase the $\beta$-glucan concentration up to $56 \%$ (Sibakov et al., 2014). A combination of fine milling and electrostatic sorting was also able to split rice straw into a cellulose-rich fraction and a lignin- and hemicellulose-rich fraction. The cellulose fraction exhibited better performances in enzymatic hydrolysis and ethanol fermentation than the starting material, while the lignin fraction can serve for chemical extraction or energy recovery (Chuetor et al., 2015). Oilseed cakes were also found to be efficiently fractionated by dry processes. Triboelectric separation was especially successful with sunflower cake (Barakat et al., 2015). A combination of ultrafine milling and electrostatic separation enabled continuous extraction of proteins from polysaccharides, lignin and polyphenols. A 50\% protein-rich fraction and a $40 \%$ lignin-rich fraction were prepared, after which downstream enzymatic reactions applied to these fractions open an attractive route for producing valuable chemicals from biomass.

An advantage of the triboelectric separators is that they can operate efficiently with a wide range of particle sizes even if the constituents share similar electrical conductivities. Operating with very fine particles allows better resolution of separation, but can pose dust management problems. The drawbacks to triboelectric separators that now need to be overcome are sensitivity to ambient humidity and sample water content, binary recovery of the products which requires recycling to reach acceptable purity but to the detriment of the mass yield, and difficulties with process scale-up to industrial level.

\section{Fig. 4}

\subsubsection{Belt-type electrostatic separators (Fig. 4-b)}

Belt-type electrostatic separators exploit differences in electrical conductivities of the species to be sorted. A belt-type separator can rely on two different charging mechanisms, namely corona discharge (shower of charged ions) and electrostatic induction (transfer of charges from a charged surface) to separate good from poor conductors. In this system, all of the particles to be separated are charged with the same polarity and then conveyed by a grounded metallic belt up to the separating zone where an electric field is generated by a rotating roll electrode connected to a high voltage supply. The charge decay during conveying differs according to the particle's insulating properties. The less conductive particles, which retain more charge, are attracted by the roll 
electrode and then collected by scraping, whereas the most conductive particles, which have lost their charge, stay on the belt where they are collected separately. A 50:50 mixture of material from finely-ground wheat grain peeling (corresponding to the outer pericarp) or from isolated gluten was conveyed on a belt-type separator (Remadnia et al., 2014). As pericarp and gluten exhibited similar conductive behavior, the corona charging was not an effective solution for efficient separation, so conductive induction was recommended. Indeed, because of their flat elongated shapes exposing more contact surface to the belt, peeling particles charged more easily and underwent stronger attraction by the roll electrode whereas the less-charged spherical gluten particles were left behind and collected on the belt. Other experiments were conducted with different plant materials to better understand and optimize their separation on a belt-type electrostatic device. The study of charge decay showed that wheat semolina behaved as a conductor whereas cork and wood powders acted more as insulating materials. Results obtained on a custom-built corona electrostatic separator highlighted particle charge is not the only factor governing the separation processes. Indeed, semolina and wood particles behaved differently when used as separated powders or as a blend composed of 50\% semolina and 50\% wood (Mayer-Laigle C. et al., 2016).

The belt-type electrostatic separator is a versatile device with a large number of adjustable operating parameters, which means it can be readily adapted to various materials and conditions to obtain the best separation. The problem appears to be fixing conditions appropriate for a range of green resources. The geometry of this type of separator also makes it particularly sensitive to ambient humidity which can shield particle charges.

\section{Conclusions-Perspectives}

Fine characterization of the structure, biochemical composition and mechanical properties of the material to process has enabled deeper understanding of fractionation behavior in dry conditions, and helped develop ways to monitor tissue and precisely determine fraction composition. Moreover, models constructed based on this knowledge make it possible to expand the natural variability of the material and test the effects on fracture behavior to better define the critical factors involved.

The success of dry biorefinery schemes was found to depend on optimizing the modes of mechanical stresses by taking into account the structure and mechanical properties of the material. Ultrafine grinding cannot be considered the best solution to obtain a homogeneous material, but it generally allows better accessibility of the constitutive molecules.

Physical, chemical or biological pretreatments of the material can be applied before or at grinding and are found to decrease the energy required to rupture while enhancing the bioavailability of the material components.

The loss of differences in size, shape and density between particles has prompted the need to develop innovative processing based on other particle properties. Electrostatic separation was found particularly successful for some applications, but drawbacks are still bottlenecks for better efficiency and industrial development, including the need to control water content in the sample and the environment, the potential explosive risk, and the flowability of fine particles. 
For a better dry biorefinery, it is necessary to optimize a combination of grinding at defined size according to the composition and structure of the material with separation steps that could potentially include both classical or innovative methods, such as for separation according to density and charge. Moreover, adapted pre-treatments will help reduce the energy required for grinding and potentially increase the accessibility of biochemical compounds from the in process resources.

\section{Acknowledgments}

The authors thank the PhD and postdoctoral students who contributed to these studies; i.e. C. Antoine, E. Chichti, S. Chuetor, M. Corcel, C. Desvignes, G.G. D. Silva, V. Greffeuille, K. Heinze, Y. Hemery, M. Martelli, J. C. Motte, S. Peyron, V. Raggiri, G. Rios, V. Topin, C. Sambusiti, the main collaborators who significantly helped complete this research, i.e. L. Dascalescu (UMR 6609, U. Poitiers Angoulême), P. Delaporte (UMR 6182, Marseille), M. George (L2C, Montpellier), F. Radjai (LMGC, Montpellier), and a number of colleagues from other INRA sites, i.e. F-X. Oury (UMR GEDEC, Clermont-Ferrand), M.F Devaux, F. Guillon and L. Saulnier, (INRA Nantes), C. Lapierre (IJPB, Paris) and from UMR IATE, i.e. J. Abecassis, M. Chaurand, G. Maraval, T.-M. Lasserre, R. Pujol, A. Putois.

\section{References}

Antoine C, Castellon J, Toureille A, Rouau X, \& Dissado L. (2004c). Comparison of constitutive wheat bran tissues by dielectric spectroscopy and effect of their moisture content. Polymer International 53, 2169-2177.

Antoine C, Lullien-Pellerin V, Abecassis J, \& RouauX. (2002). Nutritional interest of the wheat seed aleurone layer. Science des Aliments, 22, 545-556.

Antoine C, Peyron S, Mabille F, Lapierre C, Bouchet B, Abecassis J, \& Rouau X. (2003). Individual contribution of grain outer layers and their cell wall structure to the mechanical properties of wheat bran. Journal of Agricultural and Food Chemistry 51, 2026-2033.

Antoine C, Peyron S, Lullien-Pellerin V, Abecassis J, \& Rouau X. (2004a). Wheat bran tissue fractionation using biochemical markers. Journal of Cereal Science 39, 387-393.

Antoine C, Lullien-Pellerin V, Abecassis J, \& Rouau X. (2004b). Effect of wheat bran ball-milling on fragmentation and marker extractability of the aleurone layer. Journal of Cereal Science 40, 275-282.

Barakat A, de Vries H, \& Rouau X. (2013). Dry fractionation process as an important step in current and future lignocellulose biorefineries: A review. Bioresource Technology 134, 362-373.

Barakat A, Jérôme F, \& Rouau X. (2015). A dry platform for separation of proteins from biomasscontaining polysaccharides, lignin, and polyphenols. ChemSusChem 8, 1161-1166.

Barakat A, Mayer-Laigle C, Solhy A, Arancon RAD, de Vries H, \& Luque R, (2014). Mechanical pretreatments of lignocellulosic biomass: towards facile and environmentally sound technologies for biofuels production. RSC Advances 4, 48109-48127.

Barron C. (2011b). Prediction of relative tissue proportions in wheat mill streams by fourier transform mid-infrared spectroscopy. Journal of Agricultural and Food Chemistry 59, 10442-10447.

Barron C, \& Rouau X. (2008). FTIR and Raman signatures of wheat grain peripheral tissues. Cereal Chemistry 85, 619-625. 
Barron C, Samson M.-F, Lullien-Pellerin V, \& Rouau X. (2011a). Wheat grain tissue proportions in milling fractions using biochemical marker measurements: Application to different wheat cultivars. Journal of Cereal Science 53, 306-311.

Berthet M-A, Mayer-Laigle C, Rouau X, Gontard N, \& Angellier-Coussy H, (2017). Sorting natural fibres: a way to better understand the role of fibre size polydiversity on the mechanical properties of biocomposites. Composites Part 1: Applied Science and Manufacturing 95, 12-21.

Chichti E, George M, Delenne J-Y, \& Lullien-Pellerin V. (2015). Changes in the starch-protein interface depending on common wheat grain hardness revealed using atomic force microscopy. Plant Science 239, 1-8.

Chichti E, George M, Delenne J-Y, Radjai F, \& Lullien-Pellerin V. (2013). Nano-mechanical properties of starch and gluten biopolymers from atomic force microscopy. European Polymer Journal 49, 37883795.

Chichti E, Lullien-Pellerin V, George M, Radjai F, Affes R, \& Delenne J-Y. (2016). Bottom-up model for understanding the effects of wheat endosperm microstructure on its mechanical strength. Journal of Food Engineering 190, 40-47.

Chuetor S, Luque R, Barron C, Solhy A, Rouau X, \& Barakat A. (2015) Innovative combined dry fractionation technologies for rice straw valorization to biofuels. Green Chemistry 17, 926-936.

Corcel M, Devaux M-F, Guillon F, \& Barron C. (2016). Comparison of UV and visible autofluorescence of wheat grain tissues in macroscopic images of cross-sections and particles. Computers and Electronics in Agriculture 127, 281-288.

Desvignes C, Chaurand M, Dubois M, Sadoudi A, Abecassis J, \& Lullien-Pellerin V. (2008). Changes in common wheat grain milling behavior and tissue mechanical properties following ozone treatment. Journal of Cereal Science 47, 245-251.

Desvignes C, Olive C, Lapierre C, Rouau X, Pollet B, \& Lullien-Pellerin V. (2006). Effects of calcium chloride treatments on wheat grain peroxidase activity and outer layer mechanical properties. Journal of the Science of Food and Agriculture 86, 1596-1603.

Galindez-Najera SP, Choomjaihan P, Barron C, Lullien-Pellerin V, \& Campbell GM. (2016) A compositional breakage equation for wheat milling. Journal of Food Engineering 182, 46-64.

Greffeuille V, Abecassis J, Bar L'Helgouac'h C, \& Lullien-Pellerin V. (2005). Differences in the aleurone layer fate between hard and soft common wheats at grain milling. Cereal Chemistry 82, 138-143.

Greffeuille V, Abecassis J, Lapierre C, \& Lullien-Pellerin V. (2006a). Bran size distribution at milling and mechanical and biochemical characterization of common wheat grain outer layers: A relationship assessment. Cereal Chemistry 83, 641-646.

Greffeuille V, Abecassis J, Rousset M, Oury F-X, Faxe A, Bar L'Helgouac'h C, \& Lullien-Pellerin V. (2006b). Grain characterization and milling behavior of near-isogenic lines differing by hardness. Theoretical Applied Genetics 114, 1-12.

Greffeuille V, Mabille F, Rousset M, Oury F-X, Abecassis J, \& Lullien-Pellerin V. (2007). Mechanical properties of outer layers from near-isogenic lines of common wheat differing in hardness. Journal of Cereal Science 45, 227-235. 
Haddad Y, Benet JC, Delenne JY, Mermet A, \& Abecassis J. (2001). Rheological behavior of wheat endosperm-proposal for classification based on the rheological characteristics of endosperm test samples. Journal of Cereal Science 34, 105-113.

Heinze K, Kiszonas AM, Murray JC, Morris CF, \& Lullien-Pellerin V. (2016). Puroindoline genes introduced into durum wheat reduce milling energy and change milling behavior similar to soft common wheats. Journal of Cereal Science 71, 183-189.

Hemery Y, Anson NM, Haavenar R, Haenen GRMM, Noort MWJ, \& Rouau X. (2010b). Dryfractionation of wheat bran increases the bioaccessibility of phenolic acids in breads made from processed bran fractions. Food Research International 43, 1429-1438.

Hemery Y, Chaurand M, Holopainen U, Lampi A-M, Lehtinen P, Piironen V, Sadoudi A, \& Rouau X. (2011a). Potential of dry fractionation of wheat bran for the development of food ingredients, part I: Influence of ultra-fine grinding. Journal of Cereal Science 53, 1-8.

Hemery $\mathrm{Y}$, Holopainen $\mathrm{U}$, Lampi A-M, Lehtinen $\mathrm{P}$, Nurmi T, Piironen $\mathrm{V}$, Edelmann $\mathrm{M}$, \& Rouau X. (2011b). Potential of dry fractionation of wheat bran for the development of food ingredients, part II: Electrostatic separation of particles. Journal of Cereal Science 53, 9-18.

Hemery Y, Lullien-Pellerin V, Rouau X, Abecassis J, Samson M-F, Åman P, von Reding W, Spoerndli C, \& Barron C. (2009a). Biochemical markers: efficient tools for the assessment of wheat grain tissue proportions in milling fractions. Journal of Cereal Science 49, 55-64.

Hemery Y, Mabille F, Martelli MR, \& Rouau X. (2010a). Influence of water content and negative temperatures on the mechanical properties of wheat bran and its constitutive layers. Journal of Food Engineering 98, 360-369.

Hemery Y, Rouau X, Dragan C, Bilici M, Beleca R, \& Dascalescu L. (2009b). Electrostatic properties of wheat bran and its constitutive layers: Influence of particle size, composition, and moisture content. Journal of Food Engineering 93, 114-124.

Jensen SA, Munck L, \& Martens H. (1982). The botanical constituents of wheat and wheat milling fractions. 1. Quantification by autofluorescence. Cereal Chemistry 59, 477-484.

Letang C, Samson M-F, Lasserre T-M, Chaurand M, \& Abecassis J. (2002). Production of starch with very low protein content from soft and hard wheat flours by jet milling and air classification. Cereal Chemistry 79, 535-543.

Loustau-Cazalet C, Sambusiti C, Buche P, Solhy A, Bilal E, Larzek M, \& Barakat A. (2016). Innovative deconstruction of biomass induced by dry chemo-mechanical activation: impact on enzymatic hydrolysis and energy efficiency. ACS Sustainable Chemical \& Engineering 4, 2689-2697.

Lullien-Pellerin V. (2012). Ozone in grain processing. In C. O'Donnell, B.K. Tiwari, P.J. Cullen \& R.G. Rice (Eds), Ozone in Food Processing (pp. 81-102). Wiley-Blackwell.

Martelli MR, Barron C, Delaporte P, Viennois G, Rouau X, \& Sadoudi A. (2009). Pulsed laser ablation: A new approach to reveal wheat outer layer properties. Journal of Cereal Science 49, 55-64.

Martelli MR, Barron C, Mabille F, Rouau X, \& Sadoudi A. (2010b). Adherence within biological multilayered systems: Development and application of a peel test on wheat grain peripheral tissues. Journal of Cereal Science 52, 83-89.

Martelli MR, Brygo F, Delaporte P, Rouau X, \& Barron C. (2011). Estimation of wheat grain tissue cohesion via laser-induced breakdown spectroscopy. Food Biophysics 6, 433-439. 
Martelli MR, Brygo F, Sadoudi A, Delaporte P, \& Barron C. (2010a) Laser-induced breakdown spectroscopy and chemometrics: A novel potential method to analyze wheat grains. Journal of Agricultural and Food Chemistry 58, 7126-7134.

Mayer-Laigle C, Cadin A, Messal S, Dascalescu L, \& Rouau X. (2016) Dry fractionation of plant material powders using an electrostatic corona separator: a model study. 5th International Congress on Green Process Engineering (GPE 2016), Franco Berruti, Western University, Canada Cedric Briens, Western University, Canada (ECl Symposium Series Eds). http://dc.engconfintl.org/gpe2016/47.

Mayolle J-E, Lullien-Pellerin V, Corbineau F, Boivin P, \& Guillard V. (2012). Water diffusion and enzyme activities during malting of barley grains: A relationship assessment. Journal of Food Engineering 109, 358-365.

Morrison WR, \& Tester RF. (1994). Properties of damaged starch granules. IV Composition of ballmilled wheat starches and of fractions obtained on hydration. Journal of Cereal Science 20, 69-77.

Motte JC, Delenne JY, Rouau X, \& Mayer-Laigle C. (2015a) Mineral-vegetal co-milling: An effective process to improve lignocellulosic biomass fine milling and to increase interweaving between mixed particles. Bioresource Technology 192, 703-710.

Motte JC, Sambusiti C. Dumas C, \& Barakat A. (2015b) Combination of dry dark fermentation and mechanical pretreatment for lignocellulosic deconstruction: an innovative strategy for biofuels and volatile fatty acids recovery. Applied Energy 147, 67-73.

Motte JC, Delenne J-Y, Barron C, Dubreucq E, \& Mayer-Laigle C. (2017) Elastic properties of packing of granulated cork: effect of particle size. Industrial Crops and Products 99, 126-134.

Oury F-X, Lasme P, Michelet C, Rousset M, Abecassis J, \& Lullien-Pellerin V. (2015). Relationships between wheat grain physical characteristics studied through near-isogenic lines with distinct puroindoline-b allele. Theoretical Applied Genetics 128, 913-929.

Perre P, Almeida G, Ayouz M, \& Frank X. (2016). New modelling approaches to predict wood properties from its cellular structure: image-based representation and meshless methods. Annals of Forest Science 73, 147-162.

Peyron S, Abecassis J, Autran J-C, \& Rouau X. (2001). Enzymatic oxidative treatments of wheat bran layers: Effects on ferulic acid composition and mechanical properties. Journal of Agricultural and Food Chemistry 49, 4694-4699.

Peyron S, Abecassis J, Autran J-C, \& Rouau X. (2002). Influence of UV exposure on phenolic acid content, mechanical properties of bran, and milling behavior of durum wheat (Triticum Durum Desf.). Cereal Chemistry 79, 726-4731.

Pujol R, Létang C, Lempereur I, Chaurand M, Mabille F, \& Abecassis J, (2000). Description of a micromill with instrumentation for measuring characteristics of wheat grain. Cereal Chemistry 77, 421-427.

Raggiri, V, Barron, C, Abecassis, J, \& Lullien-Pellerin, V. (2016). In-Depth Study of Durum Wheat Grain Tissue Distribution at Milling. Cereal Chemistry 93, 219-225.

Remadnia M, Kachi M, Messal S, Oprean A, Rouau X, \& Dascalescu L. (2014). Electrostatic separation of peeling and gluten from finely ground wheat grains. Particulate Science and Technology 32, 608615. 
Rios G, Pinson-Gadais L, Abecassis J, Zakhia-Rozis N, \& Lullien-Pellerin V. (2009). Assessment of dehulling efficiency to reduce deoxynivalenol and fusarium level in durum wheat grains. Journal of Cereal Science 49, 387-392.

Sambusiti C, Licari A, Sohly A, Aboulkas A, Cacciaguerra T, \& Barakat A. (2015) One pot dry chemomechanical deconstruction for bioethanol production from sugarcane bagasse. Bioresource Technology 181, 200-206.

Sibakov J, Abecassis J, Barron C, \& Poutanen K. (2014). Electrostatic separation combined with ultrafine grinding to produce $\beta$-glucan enriched ingredients from oat bran. Innovative Food Science and Emerging Technologies 26, 445-455.

Silva GGD, Guilbert S, \& Rouau X. (2011). Successive centrifugal grinding and sieving of wheat straw. Powder Technology 208, 266-270.

Silva GGD, Couturier M, Berrin J-G, Buleon A, \& Rouau X. (2012). Effects of grinding processes on enzymatic degradation of wheat straw. Bioresource Technology 103, 192-200.

Surget A, \& Barron C. (2005). Histologie du grain de blé. Industrie des Céréales 145, 3-7.

Symons SJ, \& Dexter JE. (1996). Aleurone and pericarp fluorescence as estimators of mill stream refinement for various Canadian wheat classes. Journal of Cereal Science 23, 73-83.

Topin V, Delenne J-Y, Radjai F, Brendel L, \& Mabille F. (2007). Strength and failure of cemented granular matter. European Physical Journal E 23, 413-429.

Topin V, Radjai F, Delenne J-Y, Sadoudi A, \& Mabille F. (2008) Wheat endosperm as a cohesive granular material. Journal of Cereal Science 47, 347-356.

Topin V, Radjai F, Delenne J-Y, \& Mabille F. (2009). Mechanical modelling of wheat hardness and fragmentation. Powder Technology 109, 215-220.

Trivelato P, Mayer-Laigle C, Barakat A, Fulcrand H, \& Aouf C, (2016). Douglas bark dry fractionation for polyphenols isolation: From forestry waste to added value products. Industrial Crops and Products $86,12-15$. 


\section{Figure 1}

\begin{tabular}{|c|c|}
\hline $\begin{array}{l}\text { Starchy endosperm ( } \approx 80-85 \%) \\
\text { Starch granules }(75-80 \%), \text { Storage } \\
\text { proteins }(9-15 \%) \text {, fibres } \\
\text { essentially arabinoxylans }(2 \%), \\
\text { lipids }(1.5-2 \%)\end{array}$ & $\begin{array}{l}\text { Aleurone layer ( } \approx 6-9 \% \text { ) } \\
\text { Fibres (arabinoxylans and } \beta \text {-glucans ( } 40 \%) \text {, } \\
\text { minerals (essentially } \mathrm{Mg}, \mathrm{Mn}, \mathrm{K} \text { ) } \\
\text { Soluble proteins (enzymes, K rich), phytic acid, } \\
\text { betain, choline, } \\
\text { lipids, B vitamins (niacin, folic acid), } \\
\text { E vitamin (tocotrienols), phenolic compounds } \\
\text { mainly in cell walls (ferulic acid, p-coumaric acid) }\end{array}$ \\
\hline Scutellum ( $\approx 1.5 \%)$ & $\begin{array}{l}\text { Inner pericarp covered } \\
\text { with Testa \& Nucellus ( } \approx 3 \% \text { ) } \\
\text { Fibres (arabinoxylans), alkylresorcinols, phenolic } \\
\text { compounds }\end{array}$ \\
\hline & $\begin{array}{l}\text { Outer pericarp ( } \approx 3 \% \text { ) } \\
\text { Fibres (arabinoxylans, cellulose, lignin, } 65 \% \text { ) } \\
\text { phenolic compounds (ferulic acid in trimeric form) }\end{array}$ \\
\hline
\end{tabular}

Embryonic axis ( $\approx 0.5-1 \%)$

Proteins (including wheat germ agglutinin),

sugars, lipids, minerals,

E vitamin (tocopherols ) 


\section{Figure 2}
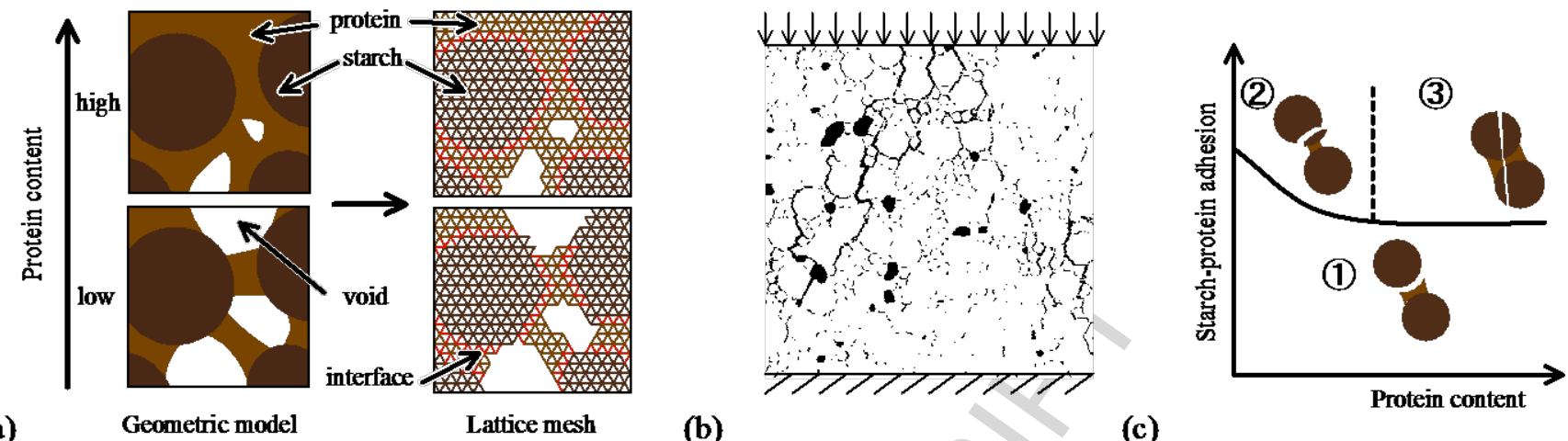

(a)

(b)

(c)

Protein content 
Figure 3

\begin{tabular}{|c|c|c|c|c|}
\hline a & Compression & Impact & Shear & Abrasion \\
\hline $\begin{array}{l}\text { TISSUE } \\
\text { SCALE }\end{array}$ & $\begin{array}{l}\text { Ball mill } \\
\text { Millstone }\end{array}$ & $\begin{array}{l}\text { Impact mill } \\
\text { Pin mill } \\
\text { Ball mill }\end{array}$ & $\begin{array}{c}\text { Knife mill } \\
\text { Centrigugal mill } \\
\text { Roll mill } \\
\text { Pin mill } \\
\text { Counter-rotating mill }\end{array}$ & $\begin{array}{l}\text { Abrasive mill } \\
\text { Attrition mill }\end{array}$ \\
\hline $\begin{array}{l}\text { CELLULAR } \\
\text { SCALE }\end{array}$ & $\begin{array}{l}\text { Ball mill } \\
\text { Millstone }\end{array}$ & $\begin{array}{l}\text { Jet mill } \\
\text { Ball mill }\end{array}$ & $\begin{array}{l}\text { High shear mill } \\
\text { Millstone }\end{array}$ & Jet mill \\
\hline
\end{tabular}

b

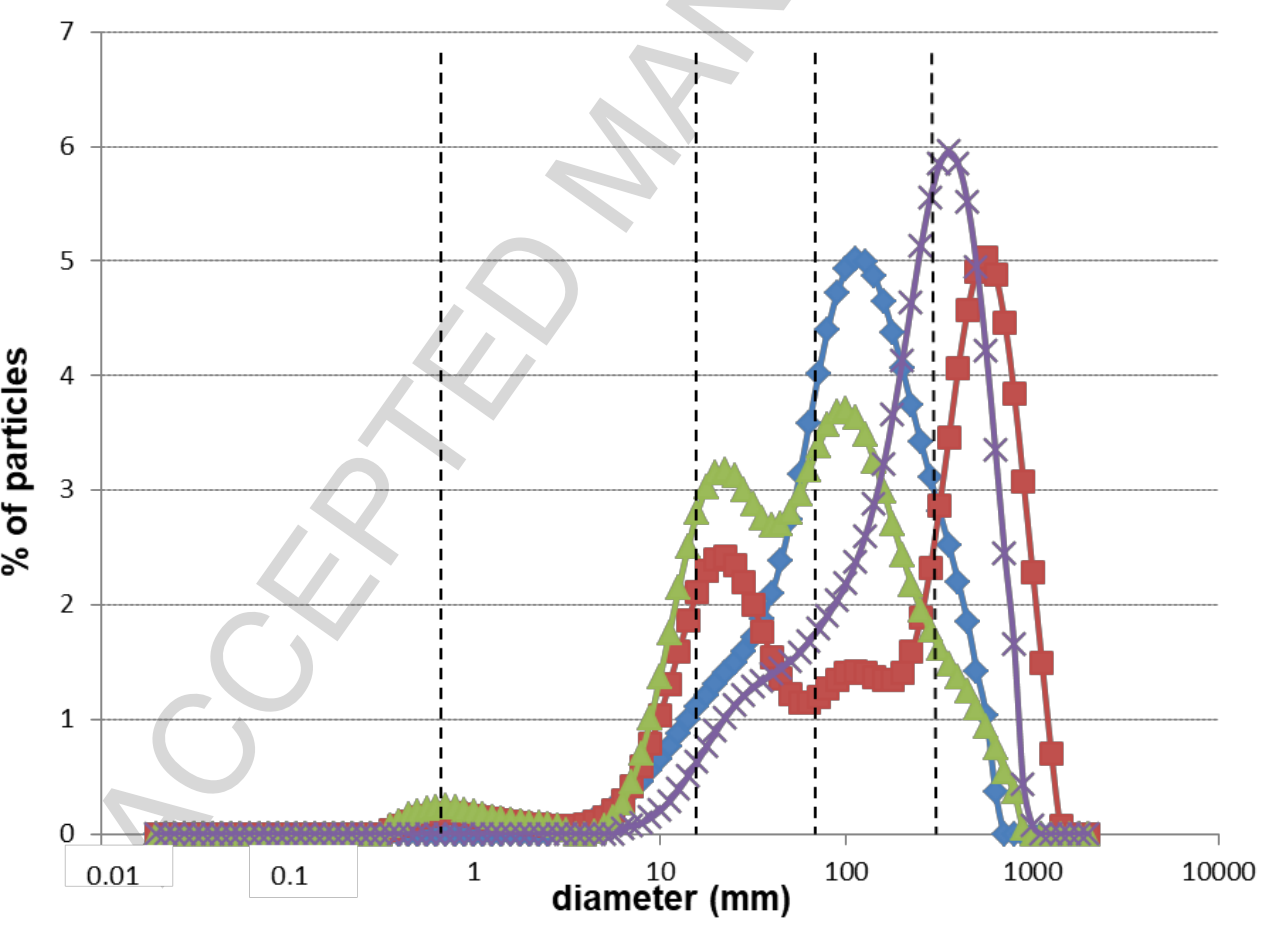




\section{Figure 4}
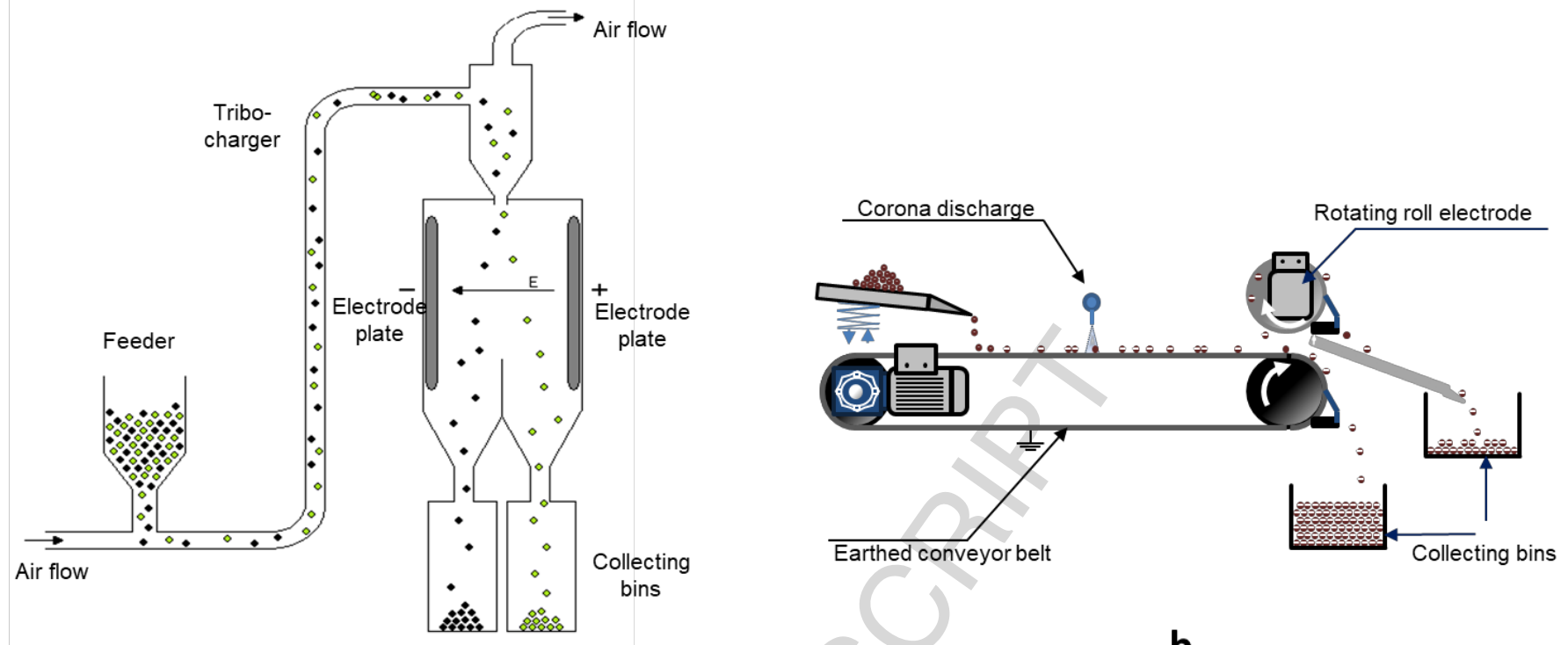

a.

b.

Comment citer ce document : 


\section{Figure captions}

\section{Fig. 1.}

Schematic representation of a cereal grain (wheat as an example), adapted from Surget \& Barron (2005), showing the various component tissues and some of their main biochemical compounds (those used as biochemical markers for the different grain tissues are underlined).

Fig. 2.

a) 2-D geometric model for the spatial distribution of phases in the wheat starchy endosperm and meshing with linear spring elements; b) Numerical simulation of a crack pattern in compression for a mealy wheat microstructure; c) Failure regimes obtained from a parametric study in which both protein content and starch-protein adhesion are varied.

\section{Fig. 3.}

a) Main mechanical stresses in different equipment enable plant material dissociation at tissue scale or cellular scale; b) Particle size distribution obtained after oat bran grinding with distinct grinding devices ( abrasive mill, $\boldsymbol{\square}$ pin mill, $\mathbf{\Delta}$ high shear mill, $\mathbf{X}$ jet mill).

\section{Fig. 4.}

Principle schemes of devices for electrostatic separation. a) Triboelectric separator; b) Belt-type electrostatic separator. 


\begin{tabular}{|c|c|c|c|c|c|c|c|c|}
\hline & \multicolumn{4}{|c|}{$\begin{array}{c}\text { Isolated mechanical properties of starchy } \\
\text { endosperm }\end{array}$} & \multicolumn{4}{|c|}{$\begin{array}{c}\text { Grain milling with an instrumented } \\
\text { micro-mill }\end{array}$} \\
\hline & $\begin{array}{c}\mathrm{E} \\
(\mathrm{MPa})\end{array}$ & $\begin{array}{c}\sigma_{\max } \\
(\mathrm{MPa})\end{array}$ & $\begin{array}{c}\varepsilon \max \\
(\%)\end{array}$ & $\begin{array}{c}\mathrm{W}_{\max } \\
\left(\mathrm{MJ} / \mathrm{m}^{3}\right)\end{array}$ & $\begin{array}{c}\text { E1 } \\
(\mathrm{kg} / \mathrm{kg} \\
\text { grains) }\end{array}$ & $\begin{array}{c}\text { First } \\
\text { break } \\
\text { flour (\%) }\end{array}$ & $\begin{array}{c}\mathrm{K}^{\prime} \\
(\mathrm{kJ} / \mathrm{kg} \\
\text { flour })\end{array}$ & $\begin{array}{c}\text { Starch } \\
\text { damage } \\
(\%)\end{array}$ \\
\hline $\begin{array}{l}\text { Soft } \\
\text { mealy } \\
\text { Soft }\end{array}$ & $560 \pm 180$ & $16.56 \pm 6.8$ & $3.61 \pm 0.93$ & $0.37 \pm 0.22$ & 9.8 & 12.3 & 80.0 & 1.9 \\
\hline $\begin{array}{l}\text { vitreous } \\
\text { Hard }\end{array}$ & $710 \pm 130$ & $18.38 \pm 5.27$ & $3.20 \pm 0.77$ & $0.35 \pm 0.13$ & 10.5 & 10.1 & 105.9 & 2.2 \\
\hline $\begin{array}{l}\text { mealy } \\
\text { Hard }\end{array}$ & $620 \pm 140$ & $28.95 \pm 7.67$ & $5.63 \pm 1.24$ & $0.93 \pm 0.37$ & 11.6 & 13.7 & 85.7 & 3.4 \\
\hline
\end{tabular}

Table 1. Grains from near-isogenic lines differing only by hardness were selected and grown in contrasted environments to obtain mealy or vitreous grains differing only by porosity level (Oury et al., 2015). Mechanical properties (Young's modulus, E; maximum stress, $\sigma$; maximum strain, $\varepsilon$, and total energy to rupture, W) were then measured in compression tests using parallelepiped-shaped samples made in the starchy endosperm of these different grains. Grains (150 g) were also milled with an instrumented micro-mill (first break and sieving) to record the grinding energy $E_{1}$ required at first break (Pujol et al., 2000) and percentage of flour (particles $<200 \mu \mathrm{m}$ ) produced. The milling index K' corresponds to the energy required to produce $1 \mathrm{~kg}$ of flour. We also measured percentage of starch damage in flour using a Megazyme assay (K-SDAM starch damage assay kit, Megazyme Int., Ireland). 


\section{Highlights}

- Specific biochemical markers help monitor tissue fate along processing

- Tissue mechanical properties determine fracture path and energy expenditure

- Numerical modeling helps expand variability and test fractionation behavior

- Innovative particle separators were developed based on their dielectric properties

- Pre-treatments before or at fractionation help reduce energy demand 